\title{
PREDIKSI SERANGAN HAMA PADA TANAMAN PADI MENGGUNAKAN JARINGAN SYARAF TIRUAN BACKPROPAGATION
}

\author{
Teguh Budi Wibowo. ${ }^{1}$, Sutikno. $^{2}$ \\ Jurusan Ilmu Komputer / Informatika, Fakultas Sains Matematika, Universitas Diponegoro \\ Jalan Prof. H. Soedarto, SH. Tembalang Semarang 50275 \\ teguh.budi46@gmail.com ${ }^{1}$, tik@ undip.ac.id ${ }^{2}$
}

\begin{abstract}
ABSTRAK
Pemanasan global telah mengakibatkan perubahan iklim yang ekstrim, diantaranya berdampak pada kenaikan suhu, perubahan curah hujan dan kelembaban udara. Sektor pertanian rentan terhadap dampak perubahan iklim karena mampu menstimulasi pertumbuhan dan perkembangan serangan Organisme Pengganggu Tanaman (OPT). Hama wereng dan hama tikus merupakan salah satu OPT pada tanaman padi. Prediksi serangan hama dapat digunakan untuk mengidentifikasi dan memantau kemunculan serangan hama sehingga luas serangan hama dapat diantisipasi dan dapat dilakukan pencegahan. Metode yang dibutuhkan untuk melakukan prediksi adalah metode yang kompleks dan dapat mempelajari ketidakpastian dalam setiap periode yang dapat diakomodasi dengan Jaringan Syaraf Tiruan (JST). Salah satu algoritma JST yaitu backpropagation, yang dapat diaplikasikan dengan baik dalam peramalan karena memiliki nilai akurasi yang tinggi. Data histori klimatologi per bulan digunakan sebagai masukan dengan luas serangan hama pada satu bulan ke depan sebagai keluaran. Arsitektur backpropagation menggunakan tiga masukan, satu layar tersembunyi dengan jumlah neuron yang dapat diubah-ubah dan satu unit keluaran. Percobaan dilakukan dengan menggunakan alfa (laju pemahaman) dari 0.3 sampai 0.7 dengan peningkatan 0.1 , nilai momentum 0.8 , jumlah neuron tersembunyi 10 sampai 100 dengan peningkatan 10, maksimum epoch 100000 , dan minimum error 0.000001 . Hasil percobaan pelatihan pada hama wereng diperoleh arsitektur jaringan terbaik adalah alfa 0.7 , jumlah neuron tersembunyi 20 dengan MSE sebesar 0.0000000027 dan pada proses pengujian diperoleh nilai MSE sebesar 0.0000005542. Percobaan pelatihan pada hama tikus diperoleh arsitektur jaringan terbaik adalah alfa 0.4, jumlah neuron tersembunyi 40 dengan MSE sebesar 0.0000009995 dan pada proses pengujian diperoleh nilai MSE sebesar 0.0830858393 .
\end{abstract}

Kata kunci : Perubahan iklim, organisme pengganggu tanaman, klimatologi, jaringan syaraf tiruan, backpropagation

\begin{abstract}
Global warming has led to extreme climate change, including impacts on temperature rise, changes in precipitation and humidity. The agricultural sector vulnerable to the effects of climate change because it is able to stimulate the growth and development of Plant Pest Organisms attack (OPT). Planthoppers and the rat is a pest in rice plants. Prediction pests can be used to identify and monitor the emergence of pests so broad pests can be anticipated and do prevention. The methods required to perform the prediction is a complex method and can learn in any period of uncertainty that can be accommodated by an Artificial Neural Network (ANN). Backpropagation architecture uses three inputs, one hidden screen with the number of neurons that can be changed and one unit of output. The experiments were performed using alpha (comprehension rate) of 0.3 to 0.7 with an increase of $0.1,0.8$ momentum value, the number of hidden neurons 10 to 100 with an increase of 10 , maximum 100000 epoch, and the minimum error 0.000001 . The experimental results obtained training on planthoppers best network architecture is the alpha of 0.7, the number of hidden neurons 20 with MSE of 0.0000000027 and the testing process values obtained MSE of 0.0000005542. Experiments in the rat training obtained the best network architecture is the alpha 0.4, the number of hidden neurons 40 with MSE of 0.0000009995 and the testing process values obtained MSE of 0.0830858393 .
\end{abstract}

Keywords: Climate change, plant pests, climatology, artificial neural network, backpropagation 


\section{PENDAHULUAN}

Pemanasan global yang terjadi akhirakhir ini, telah mengakibatkan perubahan iklim yang ektrim. Perubahan iklim mulai terjadi sejak berkembangnya dunia industri, dan hal tersebut mengakibatkan konsentrasi $\mathrm{CO}_{2}$ telah meningkat 30\% [3]. Pemanasan global juga dapat menyebabkan peningkatan intensitas kejadian iklim ekstrim (el-nino dan la-nina) dan ketidakteraturan musim.

Pertanian merupakan salah satu sektor yang sangat rentan terhadap perubahan iklim. Perubahan iklim yang berdampak pada kenaikan suhu dan perubahan curah hujan dapat membawa dampak negatif bagi sektor pertanian karena mempengaruhi produktivitas tanaman. Kabupaten Pati merupakan salah satu kabupaten dengan sektor pertanian terbesar di Jawa Tengah dengan luas 58448 hektar. Kondisi geografis yang terletak diantara pegunungan, dataran rendah dan pantai mempengaruhi kondisi iklimnya. Dampak perubahan iklim di Kabupaten Pati secara langsung maupun tidak langsung melalui serangan Organisme Pengganggu Tanaman (OPT), fluktuasi suhu dan kelembaban udara yang semakin meningkat mampu menstimulasi pertumbuhan dan perkembangan OPT.

Organisme Pengganggu Tanaman (OPT) adalah semua organisme yang dapat menyebabkan penurunan potensi hasil yang secara langsung karena menimbulkan kerusakan fisik [4]. Temperatur dan kelembaban udara relatif berpengaruh langsung terhadap siklus hidup, kemampuan berkembangbiak, lama hidup, serta kemampuan diapause serangga [8]. Dengan mengetahui iklim sebelum kejadian munculnya serangan hama maka dapat diketahui juga kemungkinan munculnya hama di masa selanjutnya. Salah satu metode yang sering digunakan proses prediksi pada jaringan syaraf tiruan adalah backpropagation.

Berdasarkan penelitian yang telah dilakukan, dapat diketahui bahwa jaringan syaraf tiruan menggunakan metode backpropagation menghasilkan tingkat

Teguh Budi : Prediksi Serangan Hama .... akurasi yang tinggi sehingga bagus untuk melakukan prediksi. Berdasarkan kondisi tersebut, maka diusulkan suatu sistem yang mampu melakukan prediksi serangan hama tanaman padi menggunakan data histori klimatologi agar dapat mengidentifikasi dan memantau kemunculan serangan hama pada tanaman sehingga serangan hama dapat diantisipasi dengan baik.

Tujuan dari penelitian ini adalah menghasilkan sebuah aplikasi prediksi serangan hama pada tanaman padi di Kabupaten Pati dengan algoritma Jaringan Syaraf Tiruan metode Backpropagation yang dapat diterapkan untuk peringatan dini serangan hama.

Adapun manfaat yang diharapkan dari penelitian tugas akhir ini adalah aplikasi dapat digunakan untuk memprediksi serangan hama tanaman pada periode bulan berikutnya.

Diharapkan pemerintah juga dapat menggunakannya sehingga dapat mengetahui jenis serangan hama yang akan muncul berdasarkan hasil prediksi untuk dilakukan tindakan antisipasi

\section{TINJAUAN PUSTAKA}

\subsection{Organisme Pengganggu Tanaman (OPT)}

Organisme pengganggu tanaman (OPT) adalah semua organisme yang dapat menyebabkan penurunan potensi hasil yang secara langsung karena menimbulkan kerusakan fisik, gangguan fisiologi dan biokimia, atau kompetisi hara terhadap tanaman budidaya. Organisme pengganggu tanaman secara garis besar dibagi menjadi tiga yaitu hama, penyakit dan gulma. Hama menimbulkan gangguan tanaman secara fisik, dapat disebabkan oleh serangga, tungau, vertebrata, moluska. [4]

Hama wereng batang coklat (WBC) dan hama tikus merupakan hama yang sering menyerang tanaman padi. Wereng batang coklat dapat menyebabkan daun berubah menjadi kuning oranye sebelum menjadi coklat dan mati. Dalam keadaan populasi wereng tinggi dan varietas yang ditanam rentan wereng, dan dapat mengakibatkan tanaman seperti terbakar atau "hopperburn". Tikus termasuk hama tanaman karena menyerang berbagai tanaman sehingga merusak dan akhirnya 
tanaman yang diserang mati. Bagian tumbuhan yang diserang tikus tidak hanya biji-bijian tetapi juga batang tumbuhan muda. Tikus biasanya tidak memakan tumbuhan yang diserang, namun hanya merusak dengan gigi-gigi mereka. Hal itu dilakukan untuk mengasah gigi tikus supaya tidak bertambah panjang. [5]

\subsection{Pengaruh Iklim Terhadap Serangan Hama}

Perkembangan hama dipengaruhi oleh faktor-faktor iklim baik langsung maupun tidak langsung. Temperatur, kelembaban udara yang relatif dan fotoperiodisitas berpengaruh langsung terhadap siklus hidup, lama hidup, serta kemampuan diapause serangga.

Penelitian yang dilakukan oleh Susanti (2008) dengan judul Dampak Perubahan Iklim terhadap Serangan Organisme Pengganggu Tanaman (OPT) Serta Strategi Antisipasi dan Adaptasi. Penelitian tersebut menyimpulkan bahwa pengaruh perubahan iklim memberikan dampak yang cukup buruk terhadap pertanian di Indonesia. Dampak tersebut bisa secara langsung maupun tidak langsung melalui serangan OPT, fluktuasi suhu dan kelembaban udara yang semakin meningkat yang mampu menstimulasi pertumbuhan dan perkembangannya. [1]

\subsection{Jaringan Syaraf Tiruan}

Jaringan Syaraf Tiruan (JST) atau yang biasa disebut Artificial Neural Network (ANN) atau Neural Network (NN) merupakan sistem pemroses informasi yang memiliki karakteristik mirip dengan jaringan syaraf pada makhluk hidup. [6] Struktur neuron pada jaringan syaraf tiruan diilustrasikan pada gambar 1 .

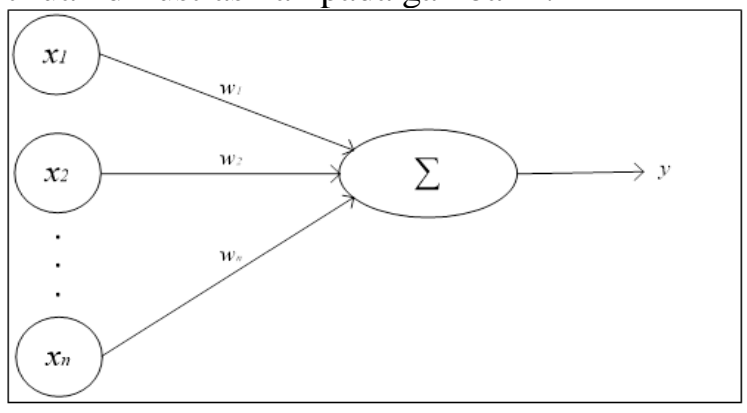

Gambar 1. Struktur neuron pada JST

Neuron $y$ menerima input dari neuron $x_{1}$, $x_{2}, \ldots, x_{n}$ dengan bobot penghubung masingmasing adalah $w_{1}, w_{2}$ dan $w_{n}$. Setiap sinyal yang masuk dikalikan dengan bobot sebelum masuk ke blok penjumlahan yang berlabel $\sum$. Kemudian blok penjumlahan akan menjumlahakan semua input terbobot dan menghasilkan sebuah nilai yaitu $y_{-} i n$.

$$
y_{-} \text {in }=\sum x_{i} w_{i}=x_{1} w_{1}+x_{2} w_{2}+\ldots+x_{n} w_{n}
$$

Aktivasi $y_{-}$in dari neuron $y$ ditentukan oleh fungsi input jaringannya, $y=f\left(y_{-}\right.$in $)$dimana $f$ merupakan fungsi aktivasi yang digunakan. Apabila nilai fungsi aktivasi cukup kuat, maka sinyal akan diteruskan. Nilai fungsi aktivasi (keluaran model jaringan) juga dapat dipakai sebagai dasar untuk merubah bobot. [7]

\subsection{Backpropagation}

Backpropagation adalah sebuah metode sistematik untuk pelatihan multiple-layer jaringan saraf tiruan. Jaringan Backpropagation sering digunakan dalam penyelesaian masalah yang rumit, hal ini dimungkinkan karena jaringan dengan algoritma ini dilatih dengan menggunakan metode belajar terbimbing. Pada jaringan diberikan sepasang pola yang terdiri dari pola masukan dan pola keluaran yang diinginkan. Ketika suatu pola diberikan kepada jaringan, bobot-bobot diubah untuk memperkecil perbedaan pola yang terdiri atas pola keluaran dan pola yang dinginkan. Latihan ini dilakukan berulang-ulang sehingga semua pola yang dikeluarkan jaringan dapat memenuhi pola yang diinginkan [2].

Backpropagation terdiri atas tiga lapisan atau lebih unit pengolah. Gambar 2 adalah arsitektur backpropagation dengan $n$ buah masukan (ditambah sebuah bias), sebuah layar tersembunyi yang terdiri dari $p$ unit (ditambah sebuah bias), serta $m$ buah unit keluaran [6].

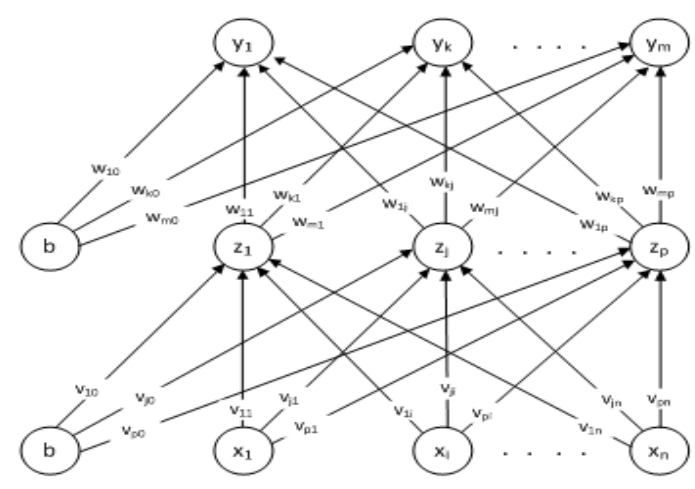

Gambar 2. Arsitektur Jaringan Backpropagation

\section{METODE PENELITIAN}

\subsection{Metode Pengumpulan Data}

Pengumpulan data dimulai dengan melakukan komunikasi dengan pihak Balai Perlindungan Tanaman dan Holtikultura (BPTPH) Provinsi Jawa Tengah mengenai 
batasan permasalahan dan requirement yang dibutuhkan.

Sistem yang dikembangkan berbasis web dengan menggunakan data klimatologi yang diambil dari Badan Meterologi Klimatologi dan Geofisika (BMKG) Jawa Tengah yang dapat dilihat pada tabel 1. Data serangan hama diambil dari Balai Perlindungan Tanaman dan Holtikultura (BPTPH) Provinsi Jawa Tengah yang dapat dilihat pada tabel 2. Data-data tersebut merupakan data untuk Kabupaten Pati.

\section{Tabel 1. Data Klimatologi}

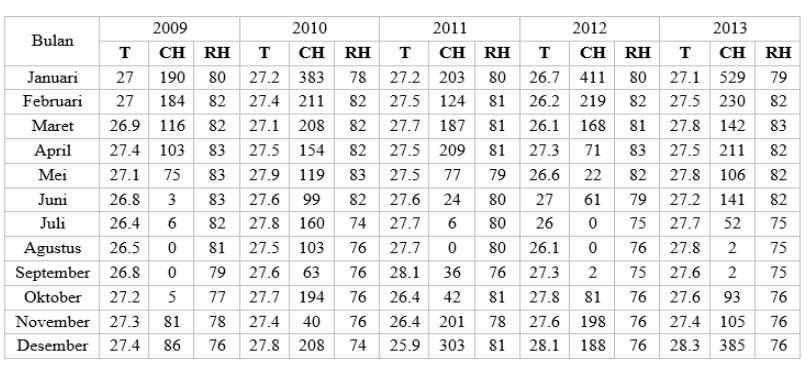

Keterangan:

$\mathrm{T}$ : Suhu Rata - Rata $\left({ }^{\circ} \mathrm{c}\right)$

RH : Kelembaban Rata - Rata (\%)

$\mathrm{CH}$ : Curah Hujan (mm)

\section{Tabel 2. Data Luas Serangan Hama}

\begin{tabular}{|c|c|c|c|c|c|c|c|c|c|c|}
\hline \multirow{2}{*}{ Bulan } & \multicolumn{2}{|c}{2009} & \multicolumn{2}{|c|}{2010} & \multicolumn{2}{c|}{2011} & \multicolumn{2}{c|}{2012} & \multicolumn{2}{c|}{2013} \\
\cline { 2 - 16 } & WBC & Tikus & WBC & Tikus & WBC & Tikus & WBC & Tikus & WBC & Tikus \\
\hline Januari & 162 & 0 & 3 & 32 & 261 & 52 & 0 & 71 & 0 & 210 \\
\hline Februari & 32 & 46 & 2 & 11 & 61 & 37 & 0 & 3 & 0 & 30 \\
\hline Maret & 63 & 24 & 16 & 68 & 43 & 279 & 0 & 25 & 0 & 3 \\
\hline April & 242 & 61 & 5 & 327 & 66 & 308 & 0 & 208 & 0 & 125 \\
\hline Mei & 1277 & 236 & 183 & 251 & 49 & 150 & 0 & 329 & 0 & 169 \\
\hline Juni & 2634 & 77 & 122 & 63 & 114 & 34 & 37 & 148 & 5 & 68 \\
\hline Juli & 1051 & 8 & 40 & 27 & 3 & 2 & 0 & 8 & 4 & 38 \\
\hline Agustus & 96 & 6 & 19 & 30 & 0 & 24 & 0 & 3 & 0 & 21 \\
\hline September & 1 & 4 & 2 & 52 & 0 & 1 & 0 & 1 & 0 & 77 \\
\hline Oktober & 0 & 58 & 3 & 431 & 0 & 63 & 0 & 14 & 0 & 80 \\
\hline November & 1 & 198 & 120 & 551 & 0 & 159 & 0 & 112 & 0 & 149 \\
\hline Desember & 0 & 223 & 415 & 291 & 0 & 115 & 0 & 209 & 0 & 249 \\
\hline
\end{tabular}

Keterangan: Luas Serangan dalam Hektar (ha)

\subsection{Model Pengambangan Sistem}

Model proses yang digunakan pada penelitian ini yaitu Prototype. Tahapantahapannya yaitu seperti pada Gambar 3 .

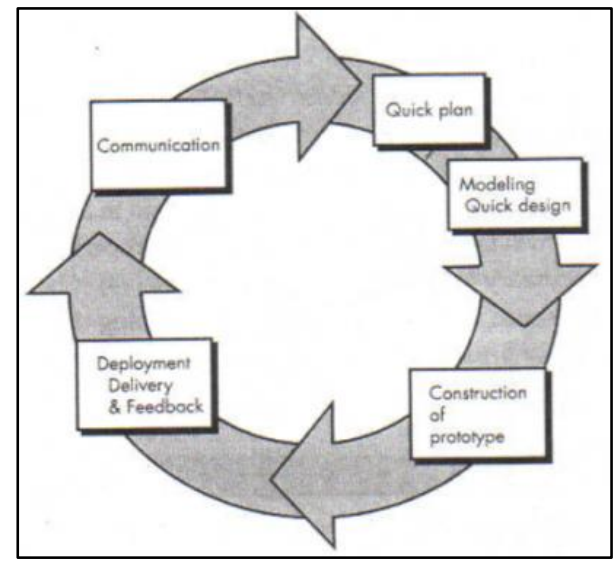

Gambar 3. Model prototype

Model proses prototype dimulai dengan tahapan communication. Pada tahapan ini, pengembang bertemu dengan stakeholder perangkat lunak untuk mendefinisikan tujuan perangkat lunak, menentukan spesifikasi kebutuhan perangkat lunak, dan batasan masalah. Kemudian dilakukan tahapan quick plan untuk menyelesaikan masalah dan solusi dari kebutuhan sistem yang telah diperoleh secara cepat dan tepat.

Aksi iterasi prototype direncanakan secara cepat dan dilakukan pemodelan dalam bentuk modelling quickdesign. Modelling Quick design berfokus pada representasi aspek-aspek perangkat lunak yang akan terlihat oleh pengguna akhir, misal interface pengguna dan format keluaran. Modelling Quick design mengarah pada pembuatan prototype.

Prototype perangkat lunak yang telah dibuat (construction) kemudian ditunjukkan (deployed) dan dievaluasi oleh stakeholder, dimana stakeholder memberikan umpan balik (feedback) yang digunakan untuk melengkapi kebutuhan perangkat lunak lebih lanjut. Iterasi dilakukan hingga kebutuhan stakeholder terpenuhi.

Pada dasarnya, prototype memberikan suatu cara untuk mengidentifikasi kebutuhan perangkat lunak. Jika sebuah prototype akan dibangun, pengembang dapat menggunakan sebagian program yang sudah ada atau mengaplikasikan tools (misalnya report generator dan window managers) yang dapat mempercepat pembuatan prototype.

\section{HASIL DAN PEMBAHASAN}

\subsection{Gambaran Umum Sistem}

Sistem prediksi ini digunakan oleh dua tipe pengguna, yaitu admin dan pengguna umum. Admin adalah pengguna yang dapat 
mengolah data, melakukan pelatihan, pengujian dan prediksi.

Secara umum arsitektur sistem pada penelitian ini yaitu seperti pada Gambar 4. Admin terlebih dahulu membuat database untuk kemudian dimasukkan data klimatologi dan data serangan hama. Data klimatologi dan data luas serangan hama tersebut kemudian dilakukan normalisasi.

Data-data tersebut kemudian digunakan untuk proses pelatihan menggunakan algoritma pelatihan backpropagation. Sehingga menghasilkan keluaran berupa bobot akhir yang akan disimpan dalam database.

Setelah bobot akhir disimpan, admin dapat melakukan pengujian dan prediksi menggunakan data klimatologi, data luas serangan hama dan data hasil pelatihan hingga didapatkan hasil pengujian dan hasil prediksi. Hasil pengujian dan prediksi kemudian disimpan dalam database. Admin dapat melihat semua data yang disimpan dalam database meliputi data klimatologi, data serangan hama, hasil pelatihan, hasil pengujian dan hasil prediksi. Pengguna umum adalah pengguna yang hanya dapat melihat data klimatologi dan data luas serangan hama serta melihat hasil prediksi yang sudah dihasilkan oleh sistem.

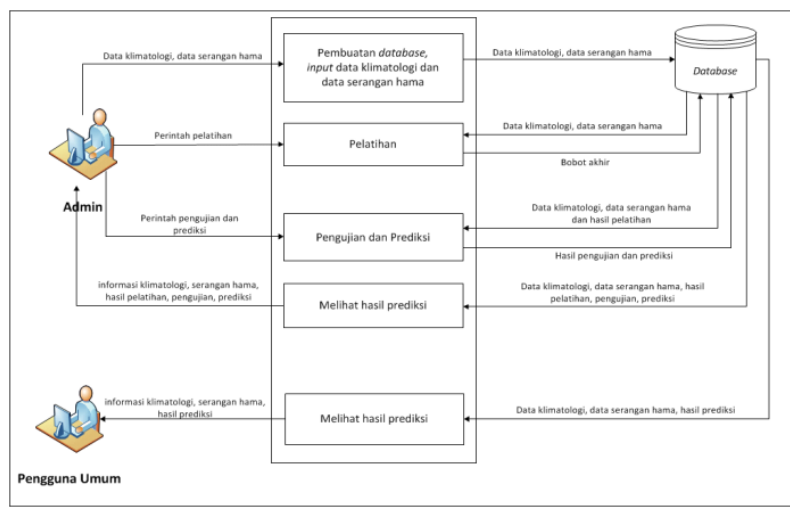

\section{Gambar 4. Arsitektur Sistem Prediksi} Serangan Hama pada Tanaman Padi

\subsection{Arsitektur Jaringan}

Data histori klimatologi per bulan digunakan sebagai masukan $\left(x_{n}\right)$ dengan luas serangan hama pada satu bulan ke depan sebagai keluaran $\left(x_{t}\right)$. Arsitektur backpropagation menggunakan tiga masukan, satu layar tersembunyi dengan jumlah neuron yang dapat diubah-ubah dan satu unit keluaran seperti pada gambar 6 .

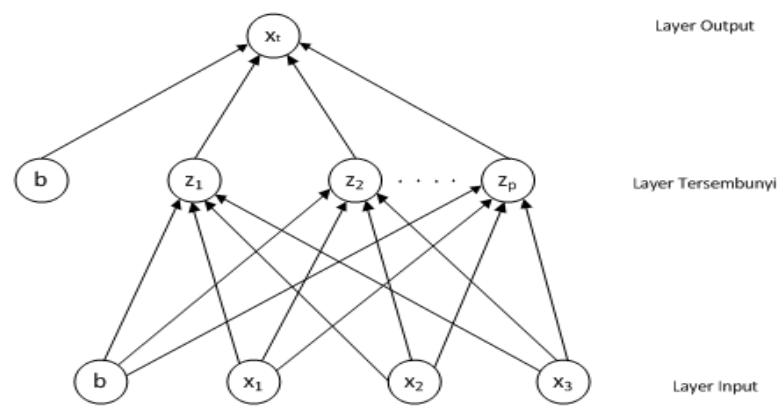

Gambar 5. Arsitektur Jaringan Sistem

\subsection{Perancangan fungsi pelatihan jaringan}

Perancangan fungsi pelatihan jaringan syaraf tiruan backpropagation digambarkan dalam flowchart pada gambar 6.

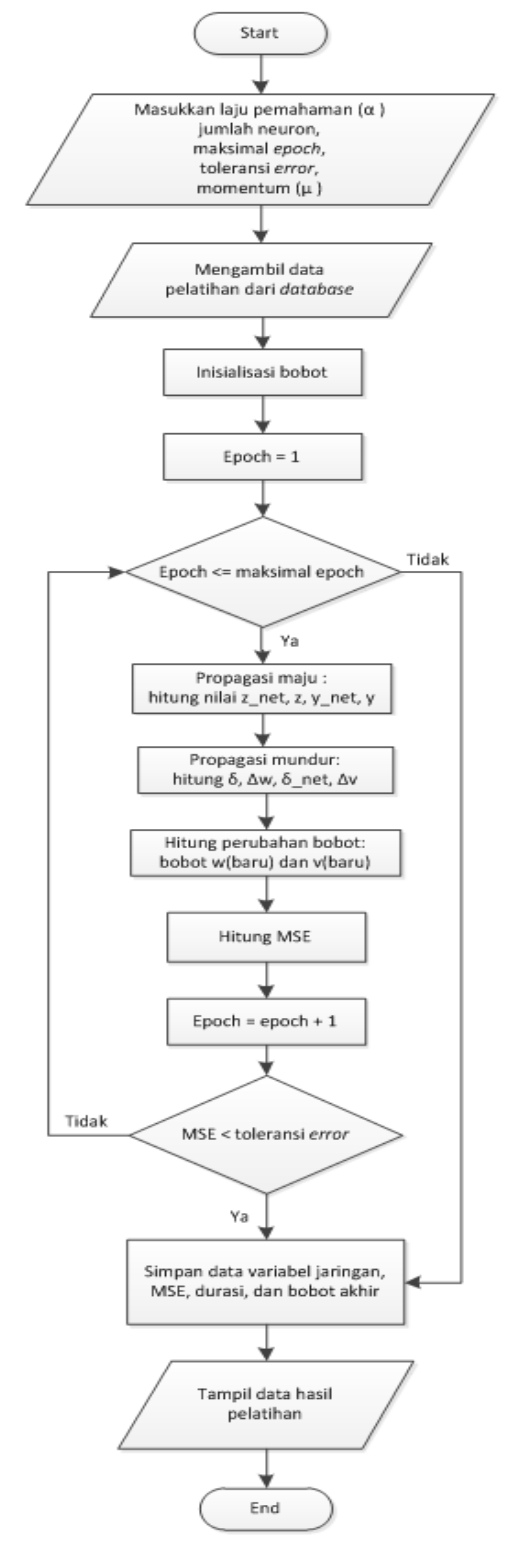

\section{Gambar 6. Diagram Alir Fungsi Pelatihan}

\subsection{Implementasi Antarmuka}

Implementasi antarmuka utama pada sistem yang dibuat yaitu antarmuka pelatihan 
jaringan dan antarmuka prediksi sepeti ditunjukkan pada gambar 7 dan 8 .

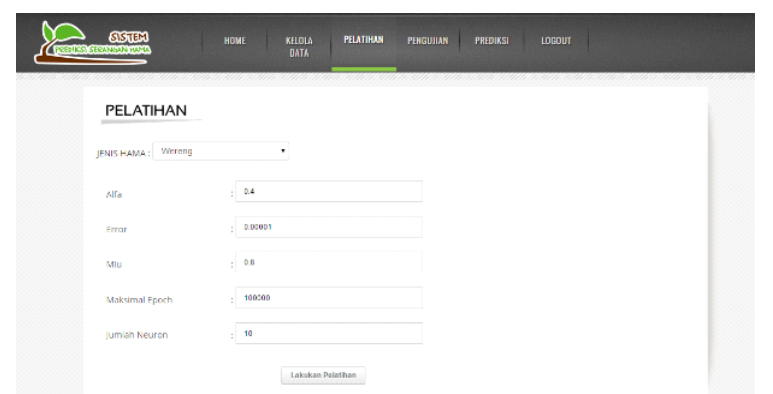

\section{Gambar 7. Implementasi Antarmuka Pelatihan}

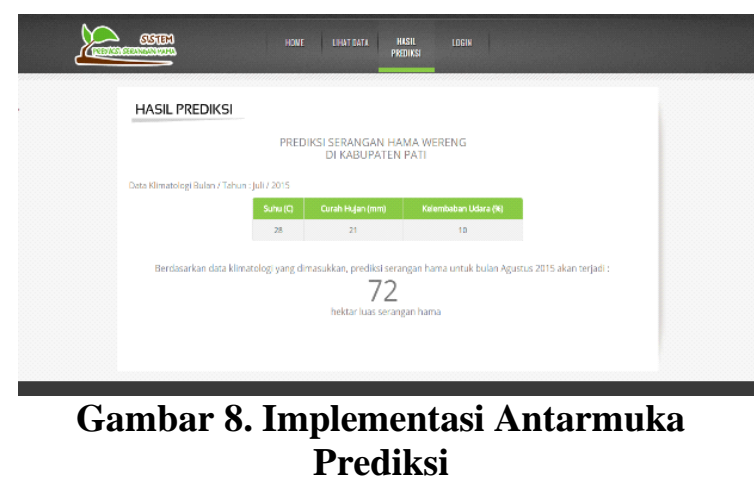

\subsection{Pengujian}

Tahap ini dilakukan percobaan pelatihan dan pengujian untuk mengetahui hasil yang dikeluarkan oleh sistem. Pelatihan dilakukan dengan memasukan momentum, minimum error dan maksimum epoch yang sama pada setiap pelatihan yaitu sebesar $0.8,0.000001$ dan 100000. Alfa yang dimasukkan semakin meningkat dari $0.3,0.4,0.5,0.6$ sampai 0.7 serta dengan neuron tersembunyi yang semakin meningkat yaitu 10, 20, 30, 40, 50, 60, 70, 80, 90, dan 100. Pelatihan menghasilkan maksimal epoch yang tercapai, MSE pelatihan dan durasi pelatihan. Kemudian dengan variabel jaringan yang sama dengan pelatihan dilakukan pengujian menggunakan data pengujian sehingga diperoleh tingkat error pengujian berdasarkan perhitungan MSE.

Data klimatologi dan data luas serangan hama yang tersedia adalah dalam kurun waktu lima tahun yaitu mulai tahun 2009 sampai 2013 dengan jumlah 60. Data dibagi menjadi dua bagian yaitu data pelatihan sebanyak $42(70 \%$ persen dari 60) dan data pengujian sebanyak 17 (30\% persen dari 60 ).

Setelah dilakukan pelatihan dan pengujian pada hama wereng didapatkan hasil terbaik dengan durasi waktu pelatihan 1 detik pada alfa 0.7, jumlah neuron tersembunyi sebanyak 20. Pelatihan berhenti pada epoch 1 dan menghasilkan MSE pelatihan sebesar Teguh Budi : Prediksi Serangan Hama ....
0.0000000027. Pada pengujian menghasilkan MSE terkecil, yaitu 0.0000005542 . Penjelasan hasil pengujian dapat dilihat pada tabel 3 .

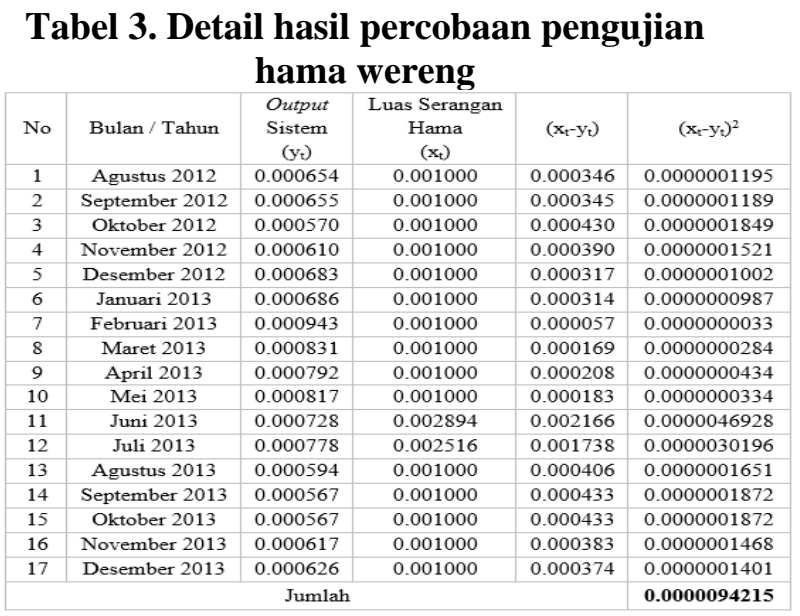

Pada hama tikus didapatkan hasil terbaik dengan durasi waktu pelatihan 49 detik pada alfa 0.4 , jumlah neuron tersembunyi sebanyak 50. Pelatihan berhenti pada epoch 1172 dan menghasilkan MSE pelatihan sebesar 0.0000003801. Pada pengujian menghasilkan MSE terkecil, yaitu 0.0367938751. Penjelasan hasil pengujian dapat dilihat pada tabel 4 .

Tabel 4. Detail hasil percobaan pengujian hama tikus

\begin{tabular}{|c|c|c|c|c|c|}
\hline No & Bulan / Tahun & $\begin{array}{l}\text { Output } \\
\text { Sistem } \\
\left(\mathrm{y}_{\mathrm{t}}\right)\end{array}$ & $\begin{array}{c}\text { Luas Serangan } \\
\text { Hama } \\
\left(\mathrm{x}_{t}\right)\end{array}$ & $\left(\mathrm{x}_{\mathrm{t}}-\mathrm{y}_{\mathrm{t}}\right)$ & $\left(x_{t}-y_{t}\right)^{2}$ \\
\hline 1 & Agustus 2012 & 0.068078 & 0.006434 & -0.061644 & 0.0037999877 \\
\hline 2 & September 2012 & 0.047626 & 0.002811 & -0.044815 & 0.0020083797 \\
\hline 3 & Oktober 2012 & 0.059131 & 0.026358 & -0.032773 & 0.0010740695 \\
\hline 4 & November 2012 & 0.048279 & 0.203860 & 0.155581 & 0.0242053853 \\
\hline 5 & Desember 2012 & 0.047939 & 0.379552 & 0.331614 & 0.1099675134 \\
\hline 6 & Januari 2013 & 0.054031 & 0.381363 & 0.327332 & 0.1071462382 \\
\hline 7 & Februari 2013 & 0.034236 & 0.055338 & 0.021101 & 0.0004452606 \\
\hline 8 & Maret 2013 & 0.015404 & 0.006434 & -0.008970 & 0.0000804652 \\
\hline 9 & April 2013 & 0.013324 & 0.227407 & 0.214083 & 0.0458314453 \\
\hline 10 & Mei 2013 & 0.015056 & 0.307102 & 0.292046 & 0.0852907493 \\
\hline 11 & Juni 2013 & 0.014473 & 0.124165 & 0.109692 & 0.0120322910 \\
\hline 12 & Juli 2013 & 0.013263 & 0.069828 & 0.056565 & 0.0031995766 \\
\hline 13 & Agustus 2013 & 0.062889 & 0.039036 & -0.023852 & 0.0005689322 \\
\hline 14 & September 2013 & 0.061888 & 0.140466 & 0.078578 & 0.0061744392 \\
\hline 15 & Oktober 2013 & 0.061888 & 0.145900 & 0.084012 & 0.0070579489 \\
\hline 16 & November 2013 & 0.046099 & 0.270877 & 0.224778 & 0.0505252392 \\
\hline 17 & Desember 2013 & 0.044463 & 0.452002 & 0.407539 & 0.1660879550 \\
\hline \multicolumn{5}{|c|}{ Jumlah } & 0.6254958764 \\
\hline
\end{tabular}

\section{KESIMPULAN}

Pelatihan jaringan syaraf tiruan backpropagation pada hama wereng menunjukkan hasil pelatihan terbaik dengan durasi waktu 1 detik pada alfa 0.7 , jumlah neuron tersembunyi sebanyak 20 . Pelatihan berhenti pada epoch 1 dan menghasilkan MSE sebesar 0.0000000027. Pada proses pengujian menghasilkan MSE terkecil, yaitu 0.0000005542. Pelatihan pada hama tikus menunjukkan hasil 
pelatihan terbaik dengan durasi waktu 49 detik pada alfa 0.4, jumlah neuron tersembunyi sebanyak 50. Pelatihan berhenti pada epoch 1172 dan menghasilkan MSE sebesar 0.0000003801. Pada proses pengujian menghasilkan MSE terkecil, yaitu 0.0367938751 .

\section{REFERENSI}

[1] Amin, Saiful, dkk. 2012. "Sistem Prediksi Dini Hama Wereng Batang Coklat Menggunakan Jaringan Syaraf Tiruan Backpropagation". Journal of Mathematics. 1(2), 118-123.

[2] Hermawan, Arief. 2006. "Jaringan Syaraf Tiruan Teori dan Aplikasi". Yogyakarta: Andi Offset.

[3] Iwantoro, S. 2008. "Pengaruh Perubahan Iklim Global terhadap Eksistensi Spesies Invasif dan Perdagangan Global". Prosiding Seminar Nasional PEI dan PFI Komda Sumsel. Palembang, 18 Oktober 2008.

[4] Lavitasari, Lisa. 2014. "Manfaat Organisme Pengganggu Tanaman". Diakses dari www.dikti.go.id/id/2014/02/10/manfaa t-organisme-pengganggu-tanaman-opt pada tanggal 23 Maret 2014, pukul 10.54 WIB.

[5] Rahmawati, Reny. 2012. "Cepat \& Tepat Berantas Hama \& Penyakit Tanaman". Yogyakarta: Pustaka Baru Press.

[6] Siang, Jong Jek. 2005. "Jaringan Syaraf Tiruan dan Pemprogramannya menggunakan Matlab". Yogyakarta: Andi Offset.

[7] Warsito, Budi. 2009. "Kapita Selekta Statistika Neural Network”. Semarang: BP Undip.

[8] Wiyono, Suryo. 2007. "Perubahan Iklim dan Pemicu Ledakan Hama dan Penyakit Tanaman". Makalah pada Seminar tentang Keanekaragaman Hayati Ditengah Perubahan Iklim: Tantangan Masa Depan Indonesia. Jakarta. 
